\title{
Article
}

\section{Anatomical Positions of Vermiform Appendix in Bangladeshi People}

\author{
Rahman MM ${ }^{1}$, Khalil M ${ }^{2}$, Rahman H ${ }^{3}$, Mannan S ${ }^{4}$, Sultana SZ ${ }^{5}$, Ahmed S ${ }^{6}$
}

The study was done to see the incidences of different anatomical positions of vermiform appendix in Bangladeshi people to increase the knowledge regarding variational anatomy in our population. A total 100 vermiform appendix (male-60, female-40) were observed in situ on cadaver of different age and sex during routine post mortem examination in the autopsy laboratory of Forensic Department of Mymensingh Medical College. This cross-sectional descriptive study was done by convenient sampling technique. For convenience of differentiating the incidences of different positions of vermiform appendix in relation to age and sex findings were classified and analyzed in four age groups (up to 20 year, 21 - 35 years, 36 - 55 years, 56 - 70 years) and in different sex.

In the present study, the pelvic position of vermiform appendix was the most common position in all age groups and pelvic positions were found in $47 \%$ cases. The retrocaecal position was the second highest position (22\%) and pre ileal position was the lowest (10\%) in number. In respect to sex, incidences of pelvic variety of vermiform appendix were more in male than female.

Key words: Vermiform appendix, anatomy, position

\section{Introduction}

A ppendicular pathology are gradually increasing in our country. As it is a blind end tube and has muscularis hiatus, end artery and sub-mucosal follicles, it is prone to infection. Besides these factors, its variable position also hampers the early diagnosis of any appendicular pathology ${ }^{1}$.

According to the many authors, the vermiform appendix is the only organ in the human body which has no single definitive anatomical position. Its position varies from individual to individual. The position of the vermiform appendix was of great interest not only because of its evolutionary significance but also because of its pathological and surgical importance. Appendicitis was a common medical problem in man at all ages from childhood to old age. The position of the organ was important in the pathogenesis, presentation,

J Bangladesh Soc Physiol. 2006 Dec;(1): 5-9 surgical approach and prognosis of the appendix related diseases ${ }^{2}$.

Identification of the normal position of the appendix is important because in appendicitis, variable positions may produce symptoms and signs related to their position and hence can mimic other diseases ${ }^{3}$.

Acute inflammatory changes are the most frequent cause of surgical abdominal interventions. Inflammation of atypically located vermiform appendix may initiate inflammation of other organs which leads to diagnostic errors and life threatening complications that it can cause. Deadly infection of the appendix at youthful age is common ${ }^{4}$.

The only thing constant about the position of the appendix was its inconstancy. No useful purpose was served by elaborate statistics of appendicular 


\section{Article}

topography in view of its great variability. Although it can not be sufficiently stressed that the position of the appendix may vary even with the posture of the individual as well as the degree of distention of the adjacent bowel. There are nevertheless two categories of surgical importance, one concerns the frequency of appendix in fixed position by adherence to the posterior abdominal wall or adjacent organs and the other with the incidence of retro caecal and retro-colic positions. ${ }^{5}$

The knowledge of variational anatomy regarding the position of appendix is very much essential when attempting to diagnose a case as appendicitis. In retrocaecal appendicitis it is difficult to found tenderness on palpation in the right iliac region. Irritation of the psoas muscle occurs in retrocaecal or para caecal appendicitis. Retrocolic appendicitis confuse with cholecystitis. In pelvic variety appendicitis, tenderness mainly elicit in the suprapubic region. Post ileal appendicitis called missed appendix and common in children and in early adult life. Perforation of preileal appendix causes more diffuse peritonitis than others. In retrocaecal and retrocolic variety of appendix, the chances of gangrenous complication are more common because their blood supply more prone to kinked ${ }^{5}$.

Pelvic variety appendix principally cause is suprapubic pain from irritation of urinary bladder. Long retro-colic inflamed appendix also called sub hepatic and it causes confusions with cholecystitis. A retrocaecal appendix may cause principally right flank or back pain. Whereas preileal directs towards the spleen and if it becomes inflamed it is liable to result in general peritonitis and is the most dangerous positions ${ }^{5}$.

With this rationale in mind, present study was done to establish a Bangladeshi standard regarding various positions of vermiform appendix which is the basic and essential for easy diagnosis and to prevent complications of appendicular pathology.

\section{Methods}

In this study, one hundred normal vermiform appendixes of both sexes(male-60, female-40) were observed in dead bodies during routine postmortem examination due to accidental and unnatural death. Vermiform appendix of the decomposed bodies \& lacerated injured cases involving appendix or its adjacent structures were excluded from the study.

In the morgue of Mymensingh Medical College, during routine postmortem examination when the abdomen was opened by classical midline incision, the position of the vermiform appendix were observed in situ and noted in the prepared format. In this study the cadaver ages were from up to 70 years (Table I).

Table I. Number of specimen in different age groups

\begin{tabular}{cccc}
\hline Group A & Group B & Group C & Group D \\
\hline Up to 20 & $21-35$ & $36-50$ & $51-70$ \\
years & years & years & years \\
$\mathrm{n}=28$ & $\mathrm{n}=39$ & $\mathrm{n}=18$ & $\mathrm{n}=15$ \\
Male $=13$ & Male $=28$ & Male $=10$ & Male $=09$ \\
$\&$ & $\&$ & $\&$ & $\&$ \\
Female & Female & Female & Female \\
$=15$ & $=11$ & $=08$ & $=06$ \\
\hline
\end{tabular}

' $n$ ' represents the number of specimens examined in each group

For convenience of differentiating the changes of vermiform appendix in relation to age, collected specimens were grouped in A group (up to 20 years), group B (21 year - 35 years), group C (36 year - 55 years) \& group D ( 56 yeas - 70 years).

\section{Results}

Positions of vermiform appendix in respect of groups (Table II and Table III):

In group A pelvic variety was highest in percentages, $35.71 \%$, total number of observation was 28 , preileal and postileal was the minimum in number of variety $(10.71 \%)$ in each.

In group B pelvic variety was maximum, in percentages $48.71 \%$, post ileal was the minimum preileal variety $(5.12 \%)$ and total number of observation was 39 .

In group C pelvic variety was $52.94 \%$. Retrocolic position was nil in position Total number of observation were 17.

J Bangladesh Soc Physiol. 2006 Dec;(1): 5-9 


\section{Article}

Table II. Positions of vermiform appendix in different age groups

\begin{tabular}{|c|c|c|c|c|c|c|c|c|c|c|c|c|}
\hline \multirow[b]{2}{*}{ 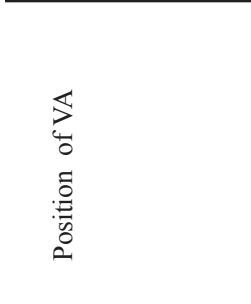 } & \multicolumn{3}{|c|}{ Group A } & \multicolumn{3}{|c|}{ Group B } & \multicolumn{3}{|c|}{ Group C } & \multicolumn{3}{|c|}{ Group D } \\
\hline & 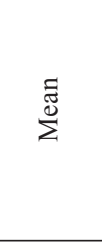 & 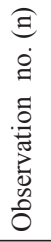 & 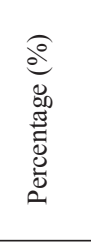 & 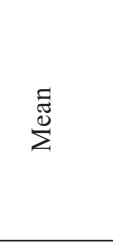 & 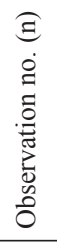 & 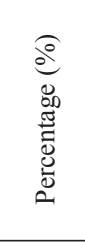 & $\frac{\Xi^{\Xi}}{\sum^{ \pm}}$ & 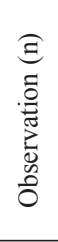 & 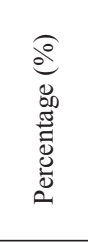 & $\stackrel{\text { }}{\stackrel{\Xi}{\Sigma}}$ & 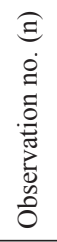 & 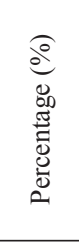 \\
\hline Retro caecal & 3.5 & 7 & 29.62 & 3.5 & 7 & 17.94 & 2.5 & 5 & 29.41 & 1.5 & 3 & 20.00 \\
\hline Retro colic & 2.0 & 4 & 14.28 & 2.0 & 2 & 10.25 & 0 & 2 & 0 & 1.0 & 2 & 13.33 \\
\hline Pelvic & 5.0 & 11 & 35.71 & 9.5 & 19 & 48.71 & 4.5 & 9 & 52.94 & 4.5 & 9 & 60.0 \\
\hline Post ileal & 1.5 & 3 & 10.71 & 1.5 & 6 & 15.38 & 0.5 & 2 & 5.88 & 0.5 & 1 & 6.66 \\
\hline Pre ileal & 1.0 & 3 & 10.71 & 4.5 & 2 & 5.12 & 0.5 & 3 & 29.41 & 0 & 0 & 0 \\
\hline Total & & 28 & & & 36 & & & 21 & & & 15 & \\
\hline Mean & 2.80 & & & 4.20 & & & 1.60 & & & 1.50 & & \\
\hline Level of significance & $\mathrm{P}<0.001$ & & & $\mathrm{P}<0.001$ & & & $\mathrm{P}<0.001$ & & & $\mathrm{P}<0.001$ & & \\
\hline
\end{tabular}

' $n$ ' represents the number of specimens examined in each group.

Group AB MS than CD, Group A MS than B, Group A S than B, Group B S than C, Group C S than D, Group A HS than $\mathrm{D}$, Here HS means highly significant, MS means moderately significant, $\mathrm{S}$ means significant

$* * * \mathrm{P}<0.001$ (HS), ** $\mathrm{P}<0.01(\mathrm{MS}), * \mathrm{P}<0.05(\mathrm{~S})$

Table III. Position of vermiform appendix in male and female

\begin{tabular}{lcccc}
\hline Position of VA & $\begin{array}{c}\text { Number of } \\
\text { observation (n) }\end{array}$ & $\begin{array}{c}\text { Male } \\
\text { Mean }\end{array}$ & $\begin{array}{c}\text { Female } \\
\text { Mean }\end{array}$ & Percentage (\%) \\
\hline R. caecal & 22 & 4.00 & 2.25 & 22 \\
R. colic & 10 & 2.00 & 0.50 & 10 \\
Pelvic & 47 & 6.75 & 4.75 & 47 \\
Post ileal & 12 & 2.00 & 0.25 & 12 \\
Pre ileal & 9 & 2.25 & 1.00 & 9 \\
Level of significance & & $\mathrm{P}<0.001$ & $\mathrm{P}<0.001$ & \\
\hline
\end{tabular}

'n' represents the number of specimens examined in each group.

Pelvic variety HS than R. Cacal, R. Cacal MS than pre ileal, Pre ileal S than R. Colic, R. Colic S than post ileal

Pelvic and R. Colic and pre ileal HS than post ileal and R. Colic, Pelvic HS than R. Cacal and pre ileal

Pelvic HS than post ileal, Here HS means highly significant, MS means moderately significant, S means significant

$* * * \mathrm{P}<0.001$ (HS), $* * \mathrm{P}<0.01(\mathrm{MS}),{ }^{*} \mathrm{P}<0.05(\mathrm{~S})$

In group D pelvic variety were $60 \%$, pre ileal position were nil in position. Total number of observation was 15 .

In all groups pelvic position was the most common position $(47 \%)$, retrocaecal $(22 \%)$ position was the second highest position in number and preileal $(10 \%)$ position was the lowest in number.

Positions of vermiform appendix in respect of age group and sex: (Table II and Table III):

J Bangladesh Soc Physiol. 2006 Dec;(1): 5-9 


\section{Article}

Here shows, 47 pelvic varieties were found in 100 specimens.

The pelvic position was maximum in respect of group and sex 47\% and its mean value was 5.75

In male its mean was 6.75 and in female its mean was 4.75. Lowest number of positional variety was pre ileal $10 \%$. Its mean was in respect to sex and group 1.62. In male its mean was 2.00 and female it was 0.25 . In all groups and sex observed that pelvic variety in male sex was maximum in number.

\section{Discussion}

In the UK on 1959 and in Ghana on 1988, at surgical removal it was found that the commonest position of the vermiform appendix was retrocaecal. In their series, found the retro-caecal position in $74 \%$ cases followed by pelvic $21 \%$, post ileal $5 \%$, para-caecal $2 \%$, sub-caecal $1.5 \%$ and pre- ileal 1\%. Kartzarski during a postmortem study found that the pelvic position was the commonest $(43.2 \%)$ in the indigineous population of Ghana ${ }^{13}$.

A study in the relative position of the vermiform appendix found that in American infants, the retro-ileal was the commonest followed by retrocaecal, pelvic, sub-caecal and ectopic ${ }^{14}$.

In 1945, Shah and shah studies 405 cases and found $45.5 \%$ retro-caecal and retro-colic, $27.4 \%$ ileio caecal, $21.5 \%$ pelvic and $5.4 \%$ sub-caecal positions ${ }^{4}$.

The position and relation between intestinum caecum and vermiform appendix are variable. Vermiform is a variable organ as for position and the place of origin from the wall of intestinum caecum. It is found that predominantly placed in the middle of the lower pole of the intestinum, caecum $(58 \%)$, in medial wall it is present in $(32 \%)$ and lateral wall in the least number cases $(10 \%)^{15}$

The vermiform appendix is subject to considerable variation in position. As the ascending colon elongates the appendix may pass posterior to the caecum (Retrocaecal appendix) or colon (Retrocolic appendix). It may also descend over the brim of the pelvis (Pelvic appendix) ${ }^{5}$
Wakeley 1933, who claimed retrocaecal position to be the commonest $65 \%$, but other investigators claimed that rectrocaecal and retrocolic position are the ${ }^{5}$.

The frequency of different position of the adult's vermiform appendix followed the above mentioned trend excepting those of Wakeley (1933) and Shah and Shah (1945). These authors recorded a high incidence of retro-caecal and retro-colic positions. It was interesting to note that Shah and Shah (1945) noted a much higher incidence of these positions in operative cases $(62 \%)$ than in cadeveric specimens $(30.1 \%)$. It was suggested that the vermiform appendix might be more liable to inflammation when fixed retro-caecally, and thus accounted for its high incidence at operation ${ }^{5}$

In Ajmani and Ajmni (1983) series, the retrocaecal and retro-colic position was the most common (58\%) followed by pelvic $(23 \%)$, post ileal (10\%), sub-caecal (5\%), pre-ileal (2\%) and para-caecal $(2 \%)$. It was possible that the frequency of the retro-caecal and retro-colic positions among the Indians might be one of the factors responsible for acute appendicitis. This was because in the retro-caecal and retro-colic positions, the blood vessels could be compressed or kinked by the caecum or ascending colon. So when the appendix was inflamed, the surgeons most commonly found it in the retro-caecal and retro-colic positions which might give it and inadequate blood supply ${ }^{7}$.

Kartzarski (1971) during a postmortem study found that the pelvic position was the commonest $43.2 \%$ in the indigenous population of Ghana. This figure was almost similar to Kartzarski and Bary, 1979 found in their series in Zambia ${ }^{14}$.

There are no explainable roles concerning the position occupied by the vermiform appendix. Wakeley (1933) studied 1000 cases and found the retrocaecal and retrocolic positions the most commonest (65.28\%), followed by the pelvic (31.1\%), sub-caecal (2.26\%), preileal (1.00\%), postileal $(0.4 \%)$ and ectopic $(0.05 \%)^{5}$

The present study (table number II.) shows that in all groups, pelvic position was the most common position.

J Bangladesh Soc Physiol. 2006 Dec;(1): 5-9 


\section{Article}

Retrocaecal was the second highest position in number, Pre-ileal was the lowest in number and, Pelvic variety was maximum in number.

It is thought that in the pelvic position, the blood vessels of the appendix are free from pressure, whereas in the retrocaecal and retro colic position the vessels are compressed or kinked by the loaded caecum or the ascending colon. ${ }^{4}$

In this study incidence of common positions of appendix did not agree with the findings of the above mentioned authors. Here, pelvic variety was found to be the most common variety instead of retrocaecal variety.

Appendicitis is a general surgeon and practitioner diagnostic reflection. For early and easy diagnosis it is very important to know about variable position of vermiform appendix in Bangladeshi people to minimize the morbidity and mortality in appendicular pathology. If we can study in living body, larger scale in different regions of Bangladesh, we shall get better information about appendix for Bangladeshi people.

\section{Author Affiliations}

*1. Curator of Anatomy, Mymensingh Medical College, Bangladesh

2. Professor of Anatomy, Mymensingh Medical College, Mymensingh, Bangladesh

3,4,5. Assistant Professor of Anatomy, Mymensingh Medical College, Mymensingh, Bangladesh

6. Lecturer of Anatomy, Mymensingh Medical College, Mymensingh, Bangladesh

* for correspondence

\section{References}

1. Datta AK. Essentials of Human Anatomy. Part - I. $6^{\text {th }}$ ed. Calcutta: Current books international; 2007, P. 228 -30 .

2. Normann LB. An introduction to the symptoms and signs of surgical disease. $3^{\text {rd }}$ ed. England: ELST; 1997. $\mathrm{p}-406-9$.

3. Bakheit MA, Warille AA. Anomalies of the vermiform appendix and prevalence of the acute appendicitis in Khartoum. King Faisal University, Dammam, Saudi Arabia. East Afr Med J, 1999; June; 76 (6): 338 - 40.
4. Schwartz SI, Principles of Surgery, $7^{\text {th }}$ ed, McGrawHill, International edition health profession Division: 1998, p. $1383-93$.

5. O'connel PR. The vermiform appendix. In: Russel RCG, Norman SW, Christopher JKB; editors Bailey's and Loves short practice of surgery. $24^{\text {th }}$ ed. London: International student ed; 2004, P.1203-18.

6. Woodburne RI. Essential's Human Anatomy. $5^{\text {th }} \mathrm{ed}$. London: Oxford University: 1973. p 430 - 33.

7. Borley NR. Editor, Microstructure of the large intestine. In: Berkovitz KBB, Borley NR, Crossman AR, Davis MS, Fitzgerald MJT, Glass J, et. al editors. Grays anatomy: the anatomical basis of clinical practice. $39^{\text {th }}$ edi, Edinburgh: Elsevier Churchill Livingstone; 2005, P. $1173-86$.

8. Snell RS. Clinical Anatomy. $7^{\text {th }}$ ed. Baltimore: Lippincott William and Wilkins; 2004. P. 215 - 7.

9. Plesis DUDJ. A Synopsis of Surgical Snatomy. $11^{\text {th }}$ ed. Bristol: John wright and sons Ltd.; 1995. P. 184

10. Moore KL, Dalley AF, editors. Clinically Orientated Anatomy. $4^{\text {th }}$ ed. Philadelphia: Lipincott Williams and Wilkins; 1999. P. $250-3$.

11. Karim OM, Borthroyd AE, Wyllic JH. Mc Burney's point-fact or friction? Ann R Coll Surg Engl. 1990 Sep; 72(5): $304-8$.

12. Shen GK, Wong R, Daller J. Does the retrocaecal position of the vermiform appendix alter the clinical course of acute appendicitis. Arch Surg, 1991 May; 126 (5): $569-70$.

13. Chowdhury GMI, Anatomical study of vermiform appendix in BD,1993. Department of Anatomy, IPGMR, Dhaka, BD, 1993.

14. Das S. A Concise Text book of Surgery. $1^{\text {st }}$ ed. Calcutta; S.D. Publishers; 1996, P.966.

15. Delic J, Savkovic A, Isakovic E. Variations in the position and point of origin of the vermiform appendix. Med Art. 2002; 56(1): 5 - 8 .

16. Lally KP, Cox CS, Andrasy RJ editor. Appendix. In: Townsend, Beauchmp, Everts, Mattox Sabiston Text book of Surgery, vol. II. $7^{\text {th }}$ ed. Saunders; 2004. P. 1381 -99 .

17. Ndoye JM, Ndiaye A, Dia A, Fall B. Cadaveric topography and morphometry of the vermiform appendix. (Article of French) faculty of medicine, Dakar Senegal. 2005 Jun; 89(285): 59 - 63.

18. Oto A, Srinivasan PN, Ernst RD. Revisiting MRI foe appendix location during pregnancy. 2006 Mar; 186(3): $883-7$. 